\title{
Students' Perception in applying lesson Study in Teaching Introduction to Linguistics
}

\author{
Ida Lisdawati \& Trisnendri Syahrizal \\ idalisdawati9088@gmail.com \\ STKIP Siliwangi Bandung
}

\begin{abstract}
Lesson Study is an approach used in learning process. It has attracted educators, experts, and professional in the area to make use of it in proving the lesson. This study focuses on the students' perception in applying Lesson study of teaching Introduction to Linguistics. As this case study, it will focus on Introduction to Linguistics subject. Interview and questionnaire was used to collects information on how Lesson study was normally conducted and observation was used to see the real implementation of Lesson study and during the teaching and learning process become a great attention here.
\end{abstract}

Keywords: lesson study, linguistics, perception

\section{Introduction}

Learning is a process faced by students to enrich their knowledge and expertise. In the general educational system, learning requires two complementary aspects namely teacher and student. Both have their respective roles that influence the success of learning process. Teachers have roles to keep learning process into a process a process of sending information making students are able to rise their ability in particular subject. While students have a role as a a benchmark in learning process. their ability to absorb the learning material depend on how the teacher handles the class and organize them using various learning methods and strategies as stated in the lesson plan as their reference during teaching.

There are many strategies and methods of learning are introduced by teachers start from a simple learning strategy that does not involve any instructional media learning until a learning strategy requires the ability to execute in an organized manner. One of the learning that provides solutions to the problems faced in the classroom is the Lesson study. This strategy exploits teachers as observers who monitor the weakness of strategies or methods implemented by other teacher in the classroom. Lesson study is used to see the weakness faced when they teach.

Based on these conditions, researchers want to know effectiveness of lesson study seen from student's perception such as how the application of lesson study in the classroom that provides new knowledge for students and the benefits felt by students during lesson study lesson study.

Lesson Study is construction professional educators through the study of collective and continuous learning based on the principles of mutual collaboration and develop a learning community (Matanlutuk, Khalid and Ovelyn, 2012). Japanese is the first country introducing Lesson Study as a learning method. Planning, implementation and reflection are steps that teachers need to use Lesson Study in classroom. Besides sharing how to make plans, they also discuss how to create the best effective teaching for student to learn about a particular lesson. 
Hollingsworth and Oliver (2005, cited in Nashruddin and Dian 2016) state that Lesson Study needs hypothesizing and anticipated student responses as essential element. hypothesizing means that how to indicate transformation referring improvement if the group of Lesson Study takes an action for solving a problem that found in classroom, while response according to Ahmadi (1992:64, cite in ) is memorizing and observation where the object has not yet in the observation time. It means student response is their memorizing and observation producing impression, so it is being awareness developed in present time or anticipating in future time.

Mulyana (2007 cited in Sudrajat, 2008 and Wakhid, 2016) state a school-based Lesson Study and MGMP-based Lesson Study are types of Lesson Study. a school-based Lesson Study is implemented by teachers and principal so that learning result can be improved. Whereas MGMP-based Lesson Study is a forum for teacher teaching the same subject to share a particular subject. According to Fernandez \&Yoshida (2004, cited in Matanlutuk, Khalid and Ovelyn, 2012) teachers cooperate to perform quantify in cycles of Lesson Study as follows:

\section{Plan a collaborative lesson plan}

In this step, teachers plan and discuss about the topic. They share about impression and idea for creating lesson plan that is compatible to the students. Textbooks, references book and teaching guide are the equipment used for making it.

\section{Implement a lesson in class}

After creating lesson plan, teachers implement the lesson plan in the classroom that consisted of students and others teachers as observers. The activity in the classroom, it is conditioned based on lesson plan. The role teacher is asked to follow it. The observers will inspect students such during the learning. They make note about what happen in the classroom for discussing in reflection session.

\section{Make discussion and to reflect on teaching.}

Reflection is the next step when role teacher has done taught. All observers give their observation and suggestion. Observers will discuss about the situation when the role teacher teach students based on the note while they sit in the classroom. in this session, the observer will rate lesson plan implementation.

\section{Modify the plan to teach}

The weakness of lesson plan will be modified in this step. The role teacher and observer swill work together for modifying it. The alteration of lesson plan will be refinement based on discussion between the role model and observers aimed to enhancement of next teaching.

\section{teach the lesson plan that has been modified}

In the next step, the role teacher will use a new lesson plan that have modified before. The role teacher will be chose from members of observers. He will implement a new lesson plan with upgrading of strategy, method and material.

\section{Shared reflections on a modified lesson plan}

It is a last step in Lesson Study. All observers will share about their suggestion, comments and idea based on the classroom situation. The finding will be noted used as a reference for next teacher in the future. 
Based on object of study, linguistics divided into two major disciplines namely micro linguistics and macro linguistics. Micro linguistics focuses on internal language structure. In micro linguistics there are several sub discipline namely phonology that discuss language sound. Morphology learning unit of word, semantics that focuses on meaning language and the last is lexicology discussing vocabulary. While micro linguistics is sub discipline focused on factors outside the language. Sub disciplines of micro linguistics are sociolinguistics, psycholinguistics, anthropology and philology.

In the Introduction to Linguistics class, the material that teacher teach are morphology, syntax, pragmatics, sociolinguistics and psycholinguistics.

\section{Morphology}

Morphology is the study of how words are structured and how they are put together from smaller parts (McManis, et al.,(1987). It not only focuses on words/morpheme, but also combination of words or morpheme in language. Morphology divided into two categories namely bound and free morpheme. McManis (1987:119) states that those morpheme which can stand alone as words are said to be free morpheme, and morpheme which always attached to some other morpheme are said be bound. Some morphemes derive new words by either changing the word meaning, or the parts of speech, or both called derivational morphemes. These morphemes which serve a purely grammatical function and never creating a different word, but only a different form of the same word called inflectional morphemes. Both of them are bound forms called affixes. In linguistics, there are three major of affixes based on its position in basis morpheme, namely prefix, infix, and suffixes.

\section{Syntax}

Syntax is the study of the structure of sentence (McManis, 1987:153). We study syntax because it enables human beings to compose complex messages. Syntax has to do with how words are put together to build phrases, with how phrases are put together to build clauses or bigger phrases, and with how clauses are put together to build sentences (Miller, 2002: xii). phrase is word group that not consist of subject and verb. It can be noun phrase, adjective phrase, and prepositional phrase. in other hand, clause has different level. It has higher level rather than phrase. Clause is word group that consists of subject and verb. It divided into two major. Firstly is independent clause and the last is dependent clause.

\section{Pragmatics}

Pragmatics is concerned with the use of these tools in meaningful communication. Pragmatics is about the interaction of semantic knowledge with our knowledge of the world, taking into account contexts of use (Griffiths, 2006:1). Dexsis, presupposition, speech acts, and implicature are parts of Pragmatics.

\section{Psycholinguistics}

Psycholinguistics is the study of the relationship between language and the mind (McManis, 1987:225). Child language acquisition is one of area that we learn in psycholinguistics.

\section{Perception}

It means that perception is the result of a process experienced by someone who received the stimulus and try to understand the situation (Feldam, 1999 cited in). there are three main components in the formation of perception. First is the selection of the sensory delivery of the stimuli from the outside which then selected. Second is the interpretation 
of the process of grouping information so that it has a meaning for someone, and the last is the conclusion of the information received (Sobur, 2009 cited in available: http: //www.libarary.binus.ac.id)

\section{Research Methodology}

Case study approach was chosen for finding the result. Introduction to Linguistic class was selected because it was one of difficult subject and researcher tried to find the solution of problem faced by students. Correspondent of this research was 38 students In this study, scale Likert was instrument used for finding the result. Correspondent would be given 15 (fifteen) question that related with the implementation of lesson study. This scale was used for measuring someone response, opinion, or perception. There were four statements that could be used as indicators for finding the result namely strongly agree, agree, not sure, disagree and strongly disagree.

\section{Result}

This study analyzed the perception of student on the implementation of Lesson Study in learning of Introduction of Linguistics. In this study, students asked 15 (fifteen) questions. The study results are based on student answer from questionnaire shared to participants. The data would explain in paragraph based on the statement.

\section{Table 1}

\begin{tabular}{|l|l|l|l|l|l|}
\hline \multirow{2}{*}{ Statement } & \multicolumn{3}{l|}{ Student's Response } \\
\cline { 2 - 6 } & $\begin{array}{l}\text { Strongly } \\
\text { Disagree }\end{array}$ & Disagree & $\begin{array}{l}\text { Not } \\
\text { Sure }\end{array}$ & Agree & $\begin{array}{l}\text { Strongly } \\
\text { Agree }\end{array}$ \\
\hline $\begin{array}{l}\text { Lesson Study makes Introduction to Linguistics } \\
\text { learning more interesting }\end{array}$ & & & 4 & 19 & 15 \\
\hline
\end{tabular}

Based on the table above, four $(10,6 \%)$ students was not sure that Lesson Study made Introduction to Linguistics learning more interesting, nineteen $(50 \%)$ students agreed that Lesson Study made Introduction to Linguistics learning more interesting, and fifteen $(39,4 \%)$ students strongly agreed that Lesson Study made Introduction to Linguistics learning more interesting.

Table 2

\begin{tabular}{|l|l|l|l|l|l|l|}
\hline \multirow{2}{*}{ statement } & \multicolumn{2}{|l|}{ Student's Response } \\
\cline { 2 - 7 } & $\begin{array}{l}\text { Strongly } \\
\text { Disagree }\end{array}$ & Disagree & $\begin{array}{l}\text { Not } \\
\text { Sure }\end{array}$ & Agree & $\begin{array}{l}\text { Strongly } \\
\text { Agree }\end{array}$ \\
\hline $\begin{array}{l}\text { The student is burdened by observers in } \\
\text { Introduction to Linguistics classroom }\end{array}$ & 1 & 4 & 14 & 14 & 4 \\
\hline
\end{tabular}


Based on the table above, one $(2,7 \%)$ student strongly agreed that he was burdened by observers in Introduction to Linguistics classroom, four $(10,6 \%)$ students agreed that they were burdened by observers in Introduction to Linguistics classroom, fourteen $(36,9 \%)$ students were not sure that they were burdened by observers in Introduction to Linguistics classroom, and four $(10,6 \%)$ students agreed that they were burdened by observers in Introduction to Linguistics classroom.

Table 3

\begin{tabular}{|l|l|l|l|l|l|}
\hline \multirow{2}{*}{ statement } & \multicolumn{3}{l|}{ Student's Response } & \multicolumn{2}{l|}{} \\
\cline { 2 - 7 } & $\begin{array}{l}\text { Strongly } \\
\text { Disagree }\end{array}$ & Disagree & $\begin{array}{l}\text { Not } \\
\text { Sure }\end{array}$ & Agree & $\begin{array}{l}\text { Strongly } \\
\text { Agree }\end{array}$ \\
\hline Lesson Study has many different methods & & 1 & 11 & 15 & 12 \\
\hline
\end{tabular}

Based on data above, one $(2,8 \%)$ student disagreed that Lesson Study had many different methods, eleven $(29 \%)$ students were not sure that that Lesson Study had many different methods, fifteen $(39,5 \%)$ students agreed that Lesson Study had many different methods and twelve $(31,6 \%)$ students strongly agreed that Lesson Study had many different methods.

Table 4

\begin{tabular}{|c|c|c|c|c|c|}
\hline \multirow{2}{*}{ statement } & \multicolumn{5}{|c|}{ Student's Response } \\
\hline & $\begin{array}{l}\text { Strongly } \\
\text { Disagree }\end{array}$ & Disagree & $\begin{array}{l}\text { Not } \\
\text { Sure }\end{array}$ & Agree & $\begin{array}{l}\text { Strongly } \\
\text { Agree }\end{array}$ \\
\hline Lesson study makes teacher more professional & & & 1 & 24 & 13 \\
\hline
\end{tabular}

Based on data above, one $(2,8 \%)$ student was not sure that Lesson study made teachers more professional, twenty four $(63,1 \%)$ students agreed that that Lesson study made teachers more professional, and thirteen $(39,5 \%)$ students agreed that Lesson Study had many different methods and twelve $(31,6 \%)$ students strongly agreed that Lesson study made teachers more professional. 
Table 5

\begin{tabular}{|l|l|l|l|l|l|l|}
\hline \multirow{2}{*}{ Statement } & \multicolumn{3}{l|}{ Student's Response } \\
\cline { 2 - 7 } & $\begin{array}{l}\text { Strongly } \\
\text { Disagree }\end{array}$ & Disagree & $\begin{array}{l}\text { Not } \\
\text { Sure }\end{array}$ & $\begin{array}{l}\text { Agre } \\
\text { e }\end{array}$ & $\begin{array}{l}\text { Strongly } \\
\text { Agree }\end{array}$ & $\begin{array}{l}\text { Abstaine } \\
\mathrm{d}\end{array}$ \\
\hline $\begin{array}{l}\text { Lesson Study makes timely teachers } \\
\text { when teaching Introduction to } \\
\text { Linguistics }\end{array}$ & & 8 & 10 & 16 & 3 & 1 \\
\hline
\end{tabular}

Based on data above, eight (21\%) students disagreed that Lesson study made timely teacher when teaching Introduction to Linguistics subject, ten $(26,3 \%)$ students were not sure Lesson study made timely teacher when teaching Introduction to Linguistics subject, sixteen $(42,2 \%)$ students agreed that sure Lesson study made timely teacher when teaching Introduction to Linguistics subject, three $(7,9 \%)$ students strongly agreed that sure Lesson study made timely teacher when teaching Introduction to Linguistics subject and one $(2,7 \%)$ abstained.

Table 6

\begin{tabular}{|l|l|l|l|l|l|}
\hline \multirow{2}{*}{ Statement } & \multicolumn{2}{l|}{ Student's Response } \\
\cline { 2 - 6 } & $\begin{array}{l}\text { Strongly } \\
\text { Disagree }\end{array}$ & Disagree & $\begin{array}{l}\text { Not } \\
\text { Sure }\end{array}$ & Agree & $\begin{array}{l}\text { Strongly } \\
\text { Agree }\end{array}$ \\
\hline $\begin{array}{l}\text { Lesson Study is increased collaboration among } \\
\text { teachers }\end{array}$ & & & 11 & 19 & 8 \\
\hline
\end{tabular}

Based on data above, eleven (29\%) student were not sure that Lesson Study has increased collaboration among teachers; nineteen (50\%) students agreed that that Lesson Study has increased collaboration among teachers, and eight (21\%) students strongly agreed that that Lesson Study has increased collaboration among teachers. 
Table 7

\begin{tabular}{|l|l|l|l|l|l|}
\hline \multirow{2}{*}{ statement } & \multicolumn{3}{l|}{ Student's Response } \\
\cline { 2 - 6 } & $\begin{array}{l}\text { Strongly } \\
\text { Disagree }\end{array}$ & Disagree & $\begin{array}{l}\text { Not } \\
\text { Sure }\end{array}$ & Agree & $\begin{array}{l}\text { Strongly } \\
\text { Agree }\end{array}$ \\
\hline $\begin{array}{l}\text { Lesson Study is increased student's } \\
\text { understanding in Introduction to Linguistics class }\end{array}$ & & 1 & 12 & 21 & 4 \\
\hline
\end{tabular}

Based on data above, one $(2,6 \%)$ student disagreed that Lesson Study has increased student's understanding in Introduction to Linguistics class, twelve $(31,6 \%)$ students were not sure that Lesson Study has increased student's understanding in Introduction to Linguistics class, twenty one $(55,2 \%)$ students agreed that Lesson Study has increased student's understanding in Introduction to Linguistics class, and four (10,5\%) students strongly agreed that Lesson Study has increased student's understanding in Introduction to Linguistics class.

Table 8

\begin{tabular}{|l|l|l|l|l|l|}
\hline \multirow{2}{*}{ statement } & \multicolumn{2}{l|}{ Student's Response } \\
\cline { 2 - 6 } & $\begin{array}{l}\text { Strongly } \\
\text { Disagree }\end{array}$ & Disagree & $\begin{array}{l}\text { Not } \\
\text { Sure }\end{array}$ & Agree & $\begin{array}{l}\text { Strongly } \\
\text { Agree }\end{array}$ \\
\hline $\begin{array}{l}\text { Lesson Study is the best way in Introduction to } \\
\text { Linguistics learning }\end{array}$ & & & 7 & 19 & 12 \\
\hline
\end{tabular}

Based on data above, seven $(18,4 \%)$ students were not sure that Lesson Study was the best way in Introduction to Linguistics learning, nineteen ( 50\%) students agreed that Lesson Study was the best way in Introduction to Linguistics learning, and twelve $(31,6 \%)$ students strongly agreed that Lesson Study was the best way in Introduction to Linguistics learning.

Table 9

\begin{tabular}{|l|l|l|l|l|l|l|}
\hline \multirow{2}{*}{ statement } & \multicolumn{3}{l|}{ Student's Response } \\
\cline { 2 - 6 } & $\begin{array}{l}\text { Strongl } \\
\text { y } \\
\text { Disagre } \\
\mathrm{e}\end{array}$ & Disagree & $\begin{array}{l}\text { Not } \\
\text { Sure }\end{array}$ & $\begin{array}{l}\text { Agre } \\
\mathrm{e}\end{array}$ & $\begin{array}{l}\text { Strongly } \\
\text { Agree }\end{array}$ & $\begin{array}{l}\text { Abstaine } \\
\mathrm{d}\end{array}$ \\
\hline $\begin{array}{l}\text { Lesson study encourages student's } \\
\text { activeness in Introduction to Linguistics } \\
\text { class }\end{array}$ & & & 6 & 23 & 13 & 1 \\
\hline
\end{tabular}


Based on data above, six (16\%) students were not sure that Lesson study encouraged student's activeness in Introduction to Linguistics class, twenty three $(60,6 \%)$ students agreed that that Lesson study encouraged student's activeness in Introduction to Linguistics class, thirteen (34,2\%) students strongly agreed that that Lesson study encouraged student's activeness in Introduction to Linguistics class, and one $(2.7 \%)$ student abstained.

Table 10

\begin{tabular}{|l|l|l|l|l|l|}
\hline \multirow{2}{*}{ statement } & \multicolumn{5}{c|}{ Student's Response } \\
\cline { 2 - 6 } & $\begin{array}{l}\text { Strongly } \\
\text { Disagree }\end{array}$ & Disagree & $\begin{array}{l}\text { Not } \\
\text { Sure }\end{array}$ & Agree & $\begin{array}{l}\text { Strongly } \\
\text { Agree }\end{array}$ \\
\hline $\begin{array}{l}\text { Lesson Study gives student new knowledge of } \\
\text { interesting method }\end{array}$ & & & 12 & 20 & 6 \\
\hline
\end{tabular}

Based on data above, twelve $(31,6 \%)$ students were not sure that Lesson Study gave student new knowledge of interesting method, twenty $(52,7 \%)$ students agreed that Lesson Study gave student new knowledge of interesting method, and six $(15,8 \%)$ students strongly agreed that Lesson Study gave student new knowledge of interesting method.

Table 11

\begin{tabular}{|l|l|l|l|l|l|}
\hline \multicolumn{2}{|c|}{ statement } & \multicolumn{5}{c|}{ Student's Response } \\
\cline { 2 - 6 } & $\begin{array}{l}\text { Strongly } \\
\text { Disagree }\end{array}$ & Disagree & $\begin{array}{l}\text { Not } \\
\text { Sure }\end{array}$ & Agree & $\begin{array}{l}\text { Strongly } \\
\text { Agree }\end{array}$ \\
\hline $\begin{array}{l}\text { Lesson Study increases student's collaboration } \\
\text { in problem solving }\end{array}$ & & 1 & 11 & 19 & 7 \\
\hline
\end{tabular}

Based on data above, one $(2,7 \%)$ student disagreed that Lesson Study increased student's collaboration in problem solving, eleven (29\%) students were not sure that Lesson Study increased student's collaboration in problem solving, nineteen (50\%) students agreed that Lesson Study increased student's collaboration in problem solving and seven $(18,4 \%)$ students strongly agreed that Lesson Study increased student's collaboration in problem solving. 
Table 12

\begin{tabular}{|l|l|l|l|l|l|}
\hline \multirow{2}{*}{ statement } & \multicolumn{3}{c|}{ Student's Response } \\
\cline { 2 - 6 } & $\begin{array}{l}\text { Strongly } \\
\text { Disagree }\end{array}$ & Disagree & $\begin{array}{l}\text { Not } \\
\text { Sure }\end{array}$ & Agree & $\begin{array}{l}\text { Strongly } \\
\text { Agree }\end{array}$ \\
\hline $\begin{array}{l}\text { Lesson Study improves student's concentration } \\
\text { in Introduction to Linguistics class }\end{array}$ & & 1 & 9 & 23 & 5 \\
\hline
\end{tabular}

Based on data above, one $(2,7 \%)$ student disagreed that Lesson Study improved student's concentration in Introduction to Linguistics class, nine $(23,7 \%)$ students were not sure that Lesson Study improved student's concentration in Introduction to Linguistics class, twenty three $(60,6 \%)$ students agreed that Lesson Study improved student's concentration in Introduction to Linguistics class, and five $(13,1 \%)$ students strongly agreed that Lesson Study improved student's concentration in Introduction to Linguistics class.

Table 13

\begin{tabular}{|l|l|l|l|l|l|l|}
\hline \multirow{2}{*}{ statement } & \multicolumn{5}{c|}{ Student's Response } \\
\cline { 2 - 7 } & $\begin{array}{l}\text { Strongly } \\
\text { Disagree }\end{array}$ & $\begin{array}{l}\text { Disagre } \\
\text { e }\end{array}$ & $\begin{array}{l}\text { Not } \\
\text { Sure }\end{array}$ & $\begin{array}{l}\text { Agre } \\
\text { e }\end{array}$ & $\begin{array}{l}\text { Strongly } \\
\text { Agree }\end{array}$ & Abstained \\
\hline $\begin{array}{l}\text { Lesson Study encourages teacher use } \\
\text { different instructional media in } \\
\text { Introduction to Linguistics class }\end{array}$ & 1 & 1 & 16 & 14 & 5 & 1 \\
\hline
\end{tabular}

Based on data above, one $(2,7 \%)$ student strongly disagree that Lesson Study encouraged teacher use different instructional media in Introduction to Linguistics class, one $(2,7 \%)$ student disagreed that Lesson Study encouraged teacher use different instructional media in Introduction to Linguistics class, sixteen $(42,1 \%)$ students were that Lesson Study encouraged teacher use different instructional media in Introduction to Linguistics class, fourteen $(36,9 \%)$ students agreed that Lesson Study encouraged teacher use different instructional media in Introduction to Linguistics class, five $(13,1 \%)$ students strongly agreed that Lesson Study encouraged teacher use different instructional media in Introduction to Linguistics class, and one $(2,7 \%)$ student abstained.

Table 14

\begin{tabular}{|l|l|l|l|l|l|}
\hline \multirow{2}{*}{ statement } & \multicolumn{5}{c|}{ Student's Response } \\
\cline { 2 - 7 } & $\begin{array}{l}\text { Strongly } \\
\text { Disagree }\end{array}$ & Disagree & $\begin{array}{l}\text { Not } \\
\text { Sure }\end{array}$ & Agree & $\begin{array}{l}\text { Strongly } \\
\text { Agree }\end{array}$ \\
\hline $\begin{array}{l}\text { Teaching through Lesson Study is not different } \\
\text { with the previous methods }\end{array}$ & 3 & 12 & 10 & 11 & 2 \\
\hline
\end{tabular}


Based on data above, three $(7,9 \%)$ students strongly disagreed that Teaching through Lesson Study was not different with the previous methods, twelve $(31,6 \%)$ students disagreed that Teaching through Lesson Study was not different with the previous methods, ten $(26,3 \%)$ students were not sure that Teaching through Lesson Study was not different with the previous methods, eleven (29\%) students agreed that Teaching through Lesson Study was not different with the previous methods, and two $(5,2 \%)$ students strongly agreed that Teaching through Lesson Study was not different with the previous methods.

Table 15

\begin{tabular}{|l|l|l|l|l|l|l|}
\hline \multicolumn{2}{|c|}{ statement } & \multicolumn{5}{c|}{ Student's Response } \\
\cline { 3 - 7 } & & $\begin{array}{l}\text { Strongly } \\
\text { Disagree }\end{array}$ & Disagree & $\begin{array}{l}\text { Not } \\
\text { Sure }\end{array}$ & Agree & $\begin{array}{l}\text { Strongly } \\
\text { Agree }\end{array}$ \\
\hline $\begin{array}{l}\text { Lesson study makes students bored in } \\
\text { Introduction to Linguistics class }\end{array}$ & 5 & 16 & 14 & 2 & 1 \\
\hline
\end{tabular}

Based on data above, five $(13,1 \%)$ students strongly disagreed that Lesson study made students bored in Introduction to Linguistics class, sixteen $(42,15 \%)$ students disagreed that Lesson study made students bored in Introduction to Linguistics class, fourteen (36,9 $\%$ ) students were not sure that Lesson study made students bored in Introduction to Linguistics class, two $(5,2 \%)$ students agreed that Lesson study made students bored in Introduction to Linguistics class, and one $(2,7 \%)$ student strongly agreed that Lesson study made students bored in Introduction to Linguistics class.

\section{Conclusion}

Applying Lesson in Introduction to Linguistics teaching gives good effect not only for students as subject of the study, but also for teachers who involved as observers. Based on the result this study, students get new alteration of learning style such as with Lesson study, they know new method that can used I the classroom, so they can imitate it when they teach their student in the future, Almost students agree that Lesson study increase their concentration. It means that students can get points of teacher's explanation. Instructional media is a basic problem faced by teacher in teaching. With lesson study, teacher forced to create an interesting teaching. They will try to use different method in every meeting. Jigsaw, throwing ball, and small discussion are several methods that can be used teacher in the classroom. This situation makes students more interested to learn it. Based on student's perception, Lesson study produces good impact in learning activity especially in Introduction to Linguistics. 


\section{References}

Griffiths, Patrick. (2006). An Introduction to English Semantics and Pragmatics. Edinburgh University Press. UKMcManis, Carolyn.\&Deborah,S.\&Zhang Z. (1987). Language Files. The Ohio State University Department of Linguistics. US

Binus Library. (2017). Bab II Tinjauan Pustaka 2.2.1 Definisi Persepsi Dalam Kamus Lengkap Psikologi. Error! Hyperlink reference not valid.

Davies, Alan.,\&Catherine,E. (2004). The Handbook of Applied Linguistics. Blackwell Publsihing. Australia

Dawson,Catherine. (2002). Practical Research Methods: A user-friendly guide to mastering research techniques and projects. Cromwell.UK

Doig,Bria.,\&Susi,grove. (2011). Japanese Lesson Study: Teacher Professional Developmentthrough Comunities of Inquiry. Mathematics Teacher Education and Development. Vol 13.1 77-93

Dominguez, Joaquin A. (1991). The Role of Morphology in the Process of Language Acquisition and Learning. Revista Alicantina de Estudio Ingleses. Vol4 37-47

Kracht,Marcus. (2007). Introductio to Linguistics. Departement of Linguistics, UNLA. Los Angeles

Matanluk, Katina.\& Khalid, J.\& Ovelyn,M. (2012) Elsevier Journal. The Perception of Teachers and Students toward Lesson Study Implementation at Rural School of Sabah: A Pilot Study.

Procedia - Social and Behavioral Sciences 90 (2013) 245 - 250.

Miller, Jim. (2002). An Introduction to English Syntax. Edinburgh University Press. UK

Nashruddin,Wakhid., Dian N. (2016). The Implementation of Lesson Study in English Language Learning: A Case Study. Dinamika Ilmu. Vol 16 (2) 169-178

Riduwan. (2012). Belajar Mudah Penelitian until Guru-Karyawan dan Peneliti Pemula. Alfa. Banding

Tracy,Sarah J. (2013). Qualitative Research Methods: Colecting, Evidence, Crafting Analysis, Communicating Impact. Wiley-Blackwell. UK

Yule, George. (1996). Pragmatics. Oxford University Press. UK

Wagner,L.,\&Lauren,D.,\&Letitia,R. (2009). Children's Early Productivity with verbal Morphology. Cognitive Development. Vol 24 223-239.

Zaccarella, E. \&Lars,Mr.,\&Michiru,M.\&Angela,D. (2017). Building by Syntax: The NeuralBasis of Minimal Linguistic Structure. Ceberal Cortex.Vol 27 411-421. 